Article

\title{
Kepentingan Ekonomi Rwanda dalam Perang Kongo
}

\author{
Arinaldo Habib Pratama 1 \\ ${ }^{1}$ Prodi Manajemen Pertahanan, Fakultas Manajemen Pertahanan, Universitas Pertahanan, \\ Indonesia
}

\section{SUBMISSION TRACK}

Recieved: 1st January 2018

Final Revision: 10th April 2018

Available Online: 30th May 2018

KEYWORD

Rwanda, Congo War, economy interest, resource wars, mineral exploitation

\begin{abstract}
A $\quad$ B $\quad \mathbf{S}$ T $\mathbf{R}$ A $\mathbf{C}$ T
This research is conducted to understand how Rwanda is able to achieve their economic interest in Congo War, using national interest and resource wars as main concept. The result of research shows that Rwanda is able to achieve their economy interest because either Democratic Republic of Congo was unable to grasp political, security and also economy control. The emergences of mineral world market during Congo War also contribute to Rwanda's economy interest during Congo War. Although Rwanda's economic interest in DRC could be categorized as form of illegal economy, Rwanda able to convince international community and Rwanda's people because security threat that come from inside Zaire or DRC.
\end{abstract}

\section{A B S S T R A K}

\section{KATA KUNCI}

Penelitian ini bertujuan untuk memahami bagaimana Rwanda mampu mendapatkan kepentingan ekonominya dalam Perang Kongo dengan menggunakan kepentingan nasional dan perang sumber daya sebagai konsep utama. Hasil dari penelitian ini menunjukkan bahwa Rwanda mampu mendapatkan kepentingan ekonominya karena Republik Demokratik Kongo tidak mampu untuk merebut kontrol politik, keamanan dan ekonomi. Keberadaan pasar mineral dunia selama Perang Kongo juga berkontribusi bagi kepentingan ekonomi Rwanda selama Perang Kongo. Meskipun kepentingan ekonomi Rwanda di DRC bisa dikategorisasi sebagai bentuk dari ekonomi ilegal, Rwanda mampu meyakinkan komunitas internasional dan masyarakat Rwanda karena ancaman keamanan yang datang dari dalam Zaire atau DRC

\section{PENDAHULUAN}

Penelitian ini bertujuan untuk menjelaskan kepentingan ekonomi Rwanda sebagai negara yang melakukan invasi dalam Perang Kongo Pertama yang berlangsung selama tahun 1996-1997 dan Perang Kongo Kedua, selama tahun 1998$2003^{1}$. Sebagai salah satu negara yang turut berpartisipasi dalam Perang Kongo, Rwanda sebetulnya tidak memiliki kapabilitas yang cukup dalam melakukan invasi. Ketidakmampuan dari angkatan bersenjata Rwanda sebelum Perang Kongo karena embargo persenjataan yang diberlakukan ke negara tersebut selama genosida berlangsung.

Sebelum dimulainya Perang Kongo

${ }^{1}$ Sasha Lezhnev dan John Prendergast, Rwanda"s Stake in Congo: Understanding Interests to Achieve Peace, Enough ! Project, hal.5 pada tahun 1996, Rwanda mengalami apa yang dinamakan genosida. Genosida di Rwanda berlangsung ketika milisi Hutu dari yang berpihak pada Presiden Rwanda yang juga seorang Hutu, Juvenil Habyarimana, melakukan pembantaian terhadap etnis Tutsi karena dianggap telah memberikan dukungan kepada Rwanda Patriotic Front (RPF) ${ }^{2}$.

RPF berhasil menggulingkan pemerintahan Rwanda yang didominasi oleh etnis Hutu, namun Rwanda menghadapi berbagai masalah, terutama masalahsosial, politik dan ekonomi. Situasi yang dihadapi oleh Rwanda pada waktu itu seharusnya tidak memungkinkan negara

\footnotetext{
${ }^{2}$ Rwanda Patriotic Front (RPF) adalah kelompok bersenjata yang didirikan oleh pengungsi Tutsi yang berdiam di berbagai negara yang berdekatan dengan Rwanda
} 
tersebut untuk melakukan invasi ke Republik Demokratik Kongo ${ }^{3}$. Namun hal yang sebaliknya terjadi, Rwanda secara mengejutkan bisa terlibat dalam Perang Kongo dalam dua periode sekaligus, yakni tahun 1996-1997 dan 1997-2003.

\section{Seperti yang disebutkan} sebelumnya, Perang Kongo dibagi dalam dua periode, 1996-1997 dan 1998-2003. Pada periode pertama, perang ini berlangsung untuk menggulingkan diktator negara tersebut, Mobutu Sese Seko. Pada periode kedua, orang yang sebelumnya memimpin pemberontakan pada Perang Kongo Pertama, Laurent Kabila, memimpin negara itu dengan represif dan otoriter sehingga selama kepemimpinannya sehingga terdapat berbagai milisi bersenjata yang muncul untuk menggulingkan Kabila dari kekuasaannya.

Aktor-aktor yang terlibat dalam Perang Kongo Pertama dan Kedua terbagi dalam dua kelompok, milisi bersenjata dan negara. Keterlibatan milisi bersenjata muncul sebagai bentuk ketidakpuasan atau grievance terhadap kepemimpinan kepala negara tersebut, apakah itu Mobutu Sese Seko maupun Laurent Kabila. Sedangkan keterlibatan berbagai negara dalam perang ini dikarenakan negara- negara tersebut terlibat dalam berbagai pertempuran maupun mempersenjatai milisi-milisi bersenjata yang memulai pemberontakan atau bekerjasama dengan angkatan bersenjata Republik Demokratik Kongo. Pada Perang Kongo Pertama, para aktor yang terlibat adalah ADFL( Alliance des Forces Démocratiques pourla libération du Congo-Zaire), Zaire, Rwanda, Uganda dan Angola ${ }^{4}$. Sedangkan pada Perang Kongo Kedua, para aktor yang terlibat adalah RDK, Rwanda, Uganda, Zimbabwe, Angola, Namibia dan milisi bersenjata yang terdiri dari RCD (Rassemblement Congolaise pour la Démocratie), MLC

\footnotetext{
${ }^{3}$ Untuk selanjutnya, baik dalam penjelasan mengenai Perang Kongo Pertama dan Kedua, peneliti akan menggunakan nama Republik Demokratik Kongo, atau dengan akronim negara tersebut, RDK

${ }^{4}$ John F. Clark, The African Stakes of Congo War, Palgrave Macmillan : New York, 2002), hal. 109-125
}

(Mouvement pour la Libération du Congo) dan Mai-Mai ${ }^{5}$.

Rwanda sebagai salah satu negara yang melakukan invasi pada RDK, adalah sebuah negara kecil yang tidak berbatasan dengan laut atau landlocked, dan berbatasan dengan Uganda, Tanzania, Burundi dan RDK (Zaire pada Perang Kongo Pertama). Secara ekonomi, 90\% penduduknya bergantung pada hasil pertanian. Rwanda memiliki lahan yang terlalu sempit sehingga seringkali penduduk membuka lahan pertanian sampai taman nasional ${ }^{6}$. Secara politik, Rwanda pernah mengalami genosida pada tahun 1994 atau 2 tahun sebelum Perang Kongo Pertama dimulai. Negara tersebut mengalami genosida karena kebencian etnis Hutu yang mayoritas terhadap etnis Tutsi sebagai minoritas membuat masingmasing etnis mempersenjatai diri. Secara ekonomi, genosida mempengaruhi harga teh dan kopi sebagai komoditas utama negara tersebut dan pemerintahan Rwanda tidak mampu membiayai subsidi dengan membeli harga kopi dan teh yang dipetik petani dengan harga yang lebih mahal ${ }^{7}$. Ketika RPF berkuasa, mereka menyadari tidak akan mampu mengembalikan ekonominegaradan memperkaya diri mereka sendiri jika hanya bergantung pada ekspor kopi dan teh.

RPF dibawah pimpinan Paul Kagame langsung melakukan berbagai upaya untuk memperkuat pengaruh angkatan bersenjata baru paska genosida, Rwanda Patriotic Army atau RPA, di dalam pemerintahan. Berbagai posisi pemerintahan berada di bawah pengawasan angkatan bersenjata dan intelijen, atau beberapa peneliti menyebutnya dengan sinis sebagai „tutsifikasiee ${ }^{\text {ee }}$. Kebanyakan dari petinggi

\footnotetext{
${ }^{5}$ Ibid

${ }^{6}$ Jean Bigagaza, Carolyn Abongdan Cecile Mukarubuga, Land Scarcity, Distribution and Conflict in Rwanda, (Pretoria: Institute for Security Studies), 2002, hal. 51.

${ }^{7}$ Karol C. Boudreaux dan Puja Ahluwalia, Cautiously Optimistic: Economic Liberalization and Reconciliation in Rwanda Coffee"s Sector, hal. 147

8 Bjorn Willum, Foreign Aid to Rwanda: Totally Beneficial or Contributing to War, (Diss.,University of Copenhagen, 2001), Hal.74
} 
militer dan intelijen paska genosida adalah orang-orang yang datang dari berbagai pengungsian etnis Tutsi seperti di Uganda dan Tanzania. Kesamaan latar belakang tersebut membuat Paul Kagame yakin akan loyalitas mereka untuk memenuhi kepentingan Kagame dan golongangolongan terdekatnya. Sebelum RPF berkuasa, terdapat sistem Akazu' dimana jaringan ini digunakan untuk menjamin loyalitas pejabat dari etnis Hutu dengan pembayaran subsidi terhadap ladang kopi di Rwanda. Sistem serupa juga dijalankan oleh Kagame yakni berupa pembagian keuntungan terhadap pejabat terdekat atau patrimonialisme tidak terbatas pada subsidi bagi ladang kopi, namun juga dengan bantuan keungan yang didapatkan dari IMF dan Bank Dunia, dan juga eksploitasi sumber daya alam. Invasi ke RDK adalah salah satu upaya Kagame untuk melanggengkan sistem ini, dan para perwira militer maupun pejabat Rwanda akan diuntungkan dari kekayaan alam RDK dan Kagame pun bisa melanggengkan kekuasaan. ${ }^{10}$

\section{PEMBAHASAN}

\section{"Self-Financing War" sebagai}

Representasi Kepentingan Ekonomi

Rwanda dalam Perang Kongo

Self-Financing War, ungkapan yang digunakan Presiden Rwanda Paul Kagame untuk menggambarkan Perang Kongo, berkontribusi dalam menjelaskan bagaimana kepentingan ekonomi juga termasuk dalam perhitungan Rwanda ketika melakukan berbagai serangan ke berbagai wilayah di Republik Demokratik Kongo. Ungkapan Self-Financing War sendiri muncul dalam sebuah laporan panel PBB yang menguraikan bagaimana militer Rwanda mampu melangsungkan perang

\footnotetext{
${ }^{9}$ Akazu adalah orang-orang yang dekat dengan Presiden Paul Kagame dan kedekatan tersebut digunakan untuk memperoleh kepentingan politik atau kepentingan ekonomi tertentu

${ }^{10}$ Pernyataan ini mengutip 2 literatur utama mengenai pemerintahan otoriter di Rwanda dibawah Rwanda Patriotic Front, yakni David Booth dari UK Department of International Development yang berjudul Developmental Patrimonialism? The Case of Rwanda dan Will Jones dari Refugee Studies Center, University of Oxford yang berjudul Africa "s Illiberal State Builders
}

dengan mineral yang mereka peroleh di RDK.:

"All military experts consulted suggested that the official defense budget of Rwanda cannot alone cover the cost of their war and presence in the Democratic Republic of the Congo. The Panel concurs with President Kagame, who described the conflict in the Democratic Republic of the Congo as " $a$ self-financing war $^{11,}$,

Penggunaan istilah ini kemudian meluas, baik dalam berbagai buku maupun artikel jurnal. Jason K. Stearn, penulis buku memoar Dancing in the Glory of Monster: the Collapse of the Congo and the Great War of Africa menggunakan kata SelfSustaining yang memiliki makna yang hampir mirip dan menurut peninjau dari New York Times, Adam Hoshchild, Stearn menggunakan kata tersebut untuk menggambarkan bagaimana Rwanda mampumemperolehkeuntungan ekonomi dari eksploitasi mineral di RDK dan bahkan untuk melindungi kepentingan tersebut, Rwanda melakukan serangan terhadap negara yang menjadi aliansinya, Uganda, atas penguasaan kota-kota yang kaya berlian dan koltan di RDK ${ }^{12}$. Untuk jurnal dan artikel ilmiah, penggunaan kata SelfFinancing War dapat ditemukan dalam berbagai tulisan seperti Stolen Goods: Coltan and Conflict in the Democratic Republic of Congo, tulisan dari Dena Montague, World Policy Institute dan International Response to the Illegal Exploitation of Resource in the DRC, tulisan dari Francois Gagnon, International Crisis Group.

Sebagai kepala negara, Paul Kagame sendiri beranggapan bahwa tuduhan yang menurutnya bersifat sepihak dari PBB sangat merugikan Rwanda,

\footnotetext{
11 United Nations Security Council, Letter Dates 12 April 2001 from the Secretary General to Presiden of the Security Counclis, hal.27

12 Adam Horshchild, Explaining Congo"s Endless Civil War, New York Times, http://www.nytimes.com/2011/04/03/books /review/book-review-dancing-in-the-gloryof-monsters-the-collapse-of-the-congoand-the-great-war-of-africa-by-jason-kstearns.html?pagewanted=all\&_r=0
} 
semisal pemotongan bantuan keuangan dari negara-negara yang menjadi mitra Rwanda. Bantahan-bantahan Paul Kagame atas tuduhan tersebut dapat ditemukan dalam wawancara Majalah Times dengan Kagame di Kigali, ibukota Rwanda, pada tanggal 14 September $2012^{13}$.

Dalam wawancara tersebut, Kagame menganggap tuduhan atas eksploitasi ekonomi oleh Rwanda di RDK tersebut datang dari orang-orang yang menganggap aneh kemajuan yang diperoleh Negara tersebut setelah genosida, dan menganggap semua kekacauan yang dapat ditemukan di perbatasan RwandaRDK adalah kesalahan Rwanda:

\begin{abstract}
"If you look at the size of wealth of Congo, the question is why should it be like that? Why does Congo look like that? It shouldn"t. [Comparing us] becomes the false basis for making a judgment against us. Some people try to explain the difference by saying Rwanda must be exploiting the wealth of Congo. Do they think that"swhat lights our streets and puts up all these buildings in our city and builds our roads? That"s a very shallow way of thinking. Maybe people who raise these issues should be asking themselves a simple question: why does Congo, that has this wealth, not thrive on it? ${ }^{14}$
\end{abstract}

Terkait dengan kepentingan ekonomi Rwanda di perbatasan Rwanda-RDK, Kagame menganggap bahwa adalah suatu kesalahan untuk menuduh Rwanda memperoleh kepentingan ekonomi selama perang berlangsung, sedangkan di satu sisi, perusahaan-perusahaan yang berasal dari Amerika Serikat dan Tiongkok juga memiliki investasi di RDK:

"What right do other companies from China, America and wherever have to be in Congo that companies from Rwanda do not have? There are companies there from all over the world. We are probably the first country in the world to be accused of

\footnotetext{
${ }^{13}$ Alex Perry, Q\&A: Rwandan President Paul Kagame, Times, http://world.time.com/2012/09/14/qarwandan-president-paul-kagame/, (accessed July 7, 2015)
}

being guilty of having an economic interest somewhere. That"s common practice. How can we be guilty of that? ${ }^{15}$

Terakhir, terkait tuduhan yang menyatakan Rwanda Patriotic Front memiliki kepentingan bisnis di RDK, Kagame menjamin bahwa keuntungan yang diperoleh perusahaan-perusahaan tersebut tidak digunakan untuk mempersenjatai tentara Rwanda di RDK dan aktivitas tersebut sepenuhnya untuk bisnis dan pajak untuk pembangunan negara:

“......We only have to make sure there is no mix-up [between] what belongs to the RPF and what belongs to the state, to avoid any conflictof interest. And all along what we did was for them to invest in certain areas where other people were shy to put their money so that we achieve another objective: to really stimulate and start another activity which should benefit the country And if Rwanda"sinterest really is economic, as people say, why not call Rwanda"s bluff? Deal with the security problem. Then Rwanda would have nothing to hide behind. Our problem in Congo for 18 years has been a security problem. You are saying we're interested because of economics. Deal with the security so that it does not exist and then we can all see what crimes we are committing in our economic interests. $^{16,}$

Selanjutnya, peneliti akan menjelaskan bagaimana aktivitas ekonomi Rwanda di RDK diawasi secara penuh oleh Paul Kagame, dan bagaimana perolehan tersebut digunakan untuk memperkaya pejabat RPF dan pembiayaan pembangunan melalui pajak. Rwanda adalah sebuah negara otoriter dengan Rwanda Patriotic Front sebagai partai politik yang dominan di segala aspek kehidupan, apakah itu sosial, politik, dan ekonomi. Secara ekonomi sendiri, pencarian rente atau rent seeking sendiri umum berlangsung di Rwanda dimana partai berkuasa, RPF, terlibat di banyak 
sektor ekonomi melalui unit usaha mereka yang mana sudah berlangsung paska genosida berakhir, dimana dana yang dikumpulkan dari berbagai simpatisan RPF digunakan untuk rekonstruksi ekonomi dari Rwanda. Namun selama Perang Kongo Kedua berlangsung, rent- seeking dilakukan dengan eksploitasi sumber daya alam dari Republik Demokratik Kongo, dimana selain untuk berkontribusi bagi negara tersebut melalui pajak, hasil eksploitasi tersebut dapat digunakan untuk memperkaya pejabat-pejabat dari partai berkuasa, terutama Presiden Rwanda Paul Kagame dan kalangan terdekatnya yang dikenal denganakazu.

Salah satu unit usaha RPF yang memanfaatkan situasi vakum dari perusahaan pertambangan dunia akibat Perang Kongo Kedua adalah sebuah perusahaan yang bernama Tri Star Company ${ }^{17}$.

Perusahaan terbesar yang dimiliki RPF, yang di Rwanda sebagai partai berkuasa , adalah Tri-Star Company. Disebut terbesar karena bergerak di berbagai bidang yang terdiri dari telekomunikasi, konstruksi, pertanian, perdagangan, perbankan, dan termasuk pertambangan (anak perusahaannya, Rwanda Metals, beroperasi di RDK selama Perang Kongo). Mengutip Willum, dibawah ini daftar kepemilikan usaha yang dimiliki Tri-Star:

1. Saham (41\%) di MTN Rwandacell $S A R L$, sebuah perusahaan telepon selular, yang pada Februari 1998 memenangkan satu-satunya lisensi untuk menjual telepon selular berbasis GSM di Rwanda

2. Kepemilikan atas Intersec, sebuah perusahaan keamanan, yang menyediakan jasa keamanan kepada bisnis, kedutaan besar, dan NGO internasional yang beroperasi di Rwanda.

3. Kepemilikan Impremerie Nouvelle, sebuah industri percetakan, yang

${ }^{17}$ Bjorn Willum, Foreign Aid to Rwanda: Purely

Beneficial or Contributing to War?,

University of Copenhagen, hal. 123 sebelumnya adalah biro percetakan nasional di bawah kepemimpinan Presiden JuvenilHabyarimana

4. Kepemilikan atas Highland Flowers, sebuah perusahaan yang mengekspor bunga mawar keEropa

5. Kepemilikan atas Mutara Enterprises, sebuah perusahaan alat kantor dan furniture yang bekerjasama dengan kementerian di Rwanda.

6. Saham di Le Meridien, sebuah hotel bintang 4 di Kigali

7. Saham di Banque de Commerce, du Développement et d"Industrie (BCDI), ${ }^{18}$ yang mana menyediakan pinjaman ke RCD-Goma untuk membeli senjata menyediakan pinjaman untuk pengeluaran militer Rwanda yang kemudian dilunasi dengan hasil dari perdagangan mineral.

8. Rwanda Metals, sebuah perusahaan yang membeli koltan dari Republik Demokratik Kongo. ${ }^{19}$

Tri-Star dibentuk sebagai "Production Unit" untuk kepentingan ekonomi RPF dalam melangsungkan pemberontakan terhadap pemerintah Rwanda yang dahulunya merupakan mayoritas Hutu sampai tahun 1994, terus berkontribusi untuk keberlangsungan Rwanda dan RPF sampai Perang Kongo Kedua berakhir ${ }^{20}$. Menurut Booth, akumulasi ekonomi yang didapat oleh RPF paska genosida tahun 1994 berasal dari 3 sumber:

1. Kontribusi keuangan yang diberikan oleh pendukung RPF yang kemudian digunakan untuk

\footnotetext{
${ }^{18} 11.6 \%$ dari saham di BCDI dimiliki oleh Tri-Star, berdasarkan laporan dari organisasi perdagangan yang bernama Common Market for Eastern and Southern Africa (Comesa). Common Market for Eastern and Southern Africa, Rwandan Banking Information, memorandum, n.d., at http://www.comesa.int/states/rwanda/qrwabact.htm ${ }^{19}$ Willum, Ibid, hal.

${ }^{20}$ Will Jones, Africa"s illiberal state-

builders, Oxford: Refugee Studies Centre, hal. 16
} 
rekonstruksi ekonomi Rwanda.

2. Kelebihan laba yang didapat dari perdagangan mineral yang tidak dipajak dan tidak diketahui dari RDK selama Perang Kongo Pertama dan Kedua berlangsung, dan,

\section{Laba dari industri-industri yang mendapat proteksi daripemerintah $^{21}$.}

Keberadaan Tri-Star dan Rwanda Metals yang diisi oleh kader dan simpatisan RPF sendiri sangat menguntungkan pejabat RPF dan angkatan bersenjata Rwanda, karena dalam Vision 2020 sendiri salah satu komitmen Rwanda adalah kebijakan zero tolerance terhadap korupsi, dan RPF harus terlihat seminimal mungkin dalam terlibat aktivitas seperti itu. Tri-Star serta Rwanda Metals juga dapat dikatakan menguntungkan Rwanda karena 10 persen dari pajak yang didapatkan oleh negara tersebut berasal dari Tri- Star, dan diantaranya yakni 6 persen berasal dari eksploitasi mineral di RDK.

\section{Analisis Komersialisasi Mineral RDK oleh Militer Rwanda menggunakanPrivate Resource Diplomacy}

Dalam Perang Kongo. Rwanda melakukan komersialisasi mineral dengan bekerjasama dengan negara atau perusahaan internasional, maupun menjualnya sendiri dengan cara melalui penguasaan wilayah yang strategis dengan kepemilikan mineralnya. Private Resource Diplomacy dalam Perang Kongo Pertama ini dimulai dengan hubungan Rwanda dan Amerika Serikat yang mulai menguat paska genosida yang berlangsung tahun 1994. Saat itu, Paul Kagame yang memimpin Rwanda Patriotic Front atau RPF berhasil menghentikan genosida terhadap minoritas Tutsi di negara tersebut, dengan membuat Angkatan Bersenjata Rwanda yang mayoritas berasal dari etnis Hutu menyingkir ke dalam Zaire untuk bersembunyi. Keberhasilan RPF ini

${ }^{21}$ David Booth, Developmental patrimonialism? :The case of Rwanda,(London: Africa Power and Politics Programme), hal.4 membuat Amerika Serikat senang karena, mengutip Washington Post, mereka tidak perlu mengirim pasukannya untuk melakukan intervensi terhadap bencana kemanusiaan disana semenjak pasukan mereka dipukul mundur di Somalia pada tahun 1992. Amerika Serikat yang senang terhadap keberhasilan Rwanda tersebut memutuskan memberikan dukungan militer terhadap Rwanda:

"....became increasingly close to the
Rwandan government and the army
that backed it.... Washington
pumped military aid into Kagame s
army and U. S. Army Special
Forces and other military personnel
trained hundreds of Rwandan
forces.

Perusahaan - perusahaan seperti Barrick, American Mineral Fields (AMF), Banro Resources dan Bechtel merupakan penyokong dana utama dari kampanye Presiden Bill Clinton yang berkuasa pada waktu itu. Selain itu, bekas presiden Amerika Serikat George Bush dan bekas Perdana Menteri Mulroney merupakan dewan penasihat dari perusahaan pertambangan Barrick $^{23}$. Ini merupakan ironi bagi Presiden AS Bill Clinton yang menyerukan terjadinya Africa Rennaisance sebagai harapan agar negaranegara Afrika memperlakukan hak asasi manusia dengan lebih baik lagi ${ }^{24}$.

Militer Rwanda, diawasi oleh Presiden Rwanda, mulai melakukan eksploitasinya sendiri, dengan mengawasi tenaga kerja paksa yang mereka awasi. Hal ini dapat tercapai karena adanya $A k a z u$ dan Congo Desk. Akazu bisa dikatakan sebagai sekumpulan orang-orang yang dekat dengan Presiden Paul Kagame dan kedekatan tersebut digunakan untuk

\footnotetext{
${ }^{22}$ Ellen Ray, U.S Military and Corporate Colonization of Congo,

www.thirdworldtraveler.com/Africa/US_Recoloniza tion_Congo.html

${ }^{23}$ Wayne Madsen, US (under)mining Job, http://cryptome.org/us-africa-wm.htm

${ }^{24}$ Africa Rennaisance adalah judul pidato yang disampaikan oleh Presiden AS Bill Clinton dalam kunjungannya ke Ghana padaMaret 1998. Pada pidato tersebut, Clinton menekankan keberhasilan demokrasi dan hak asasi manusia di Afrika
} 
memperoleh kepentingan politik atau kepentingan ekonomi tertentu ${ }^{25}$. Akazu memiliki arti "rumahkecil" dalam bahasa asli Rwanda yakni bahasa Kinyarwanda. Sebelumnya, Akazu digunakan untuk kalangan terdekat dari Presiden yang berasal dari etnis Hutu, Juvenil Habyarimana yang berasal dari angkatan bersenjata Rwanda. Semenjak para perwira angkatan bersenjata Rwanda yang dekat dari Habyarimana kebanyakan berasal dari keluarga istri Habyarimana, Agathe Habyarimana, Akazu memiliki nama lain "la Clan du Madame".

Pada era Presiden Paul Kagame, Akazu terdiri dari bekas pengungsi Tutsi yang berdiam di berbagai negara yang berdekatan dengan Rwanda seperti Uganda dan Tanzania, yang kemudian menduduki berbagai posisi penting di Rwanda, terutama perwira militer dalam pemerintahan Paul Kagame:

\begin{abstract}
"Within the army, of the 45 main positions - Ministry of Defence, RPA and Gendarmerie Chiefs of Staff, and unit commanders 27,, belong "to the,,Ugandans",as against 10 to the,,Burundians", and Do ex-FAR members, 3 to the „Rwandans "and just one to the,"Zairians". Every on of the unit commanders of the RPA is "Ugandan", as are three of the five Gendarmerie commanders. Among the five existing Intelligence Services in Rwanda, the same ,Ugandan" preponderance is present today. The head of the DMI [Department of Military Intelligence], following a temporary „Burundian", is a,, Ugandan".
\end{abstract}

The head of the ESCO and his deputy are "Ugandans". The head of the Gendarmerie Intelligence Service was born in the Congo but educated in Uganda. There is also a, Ugandan" at the head of Special Intelligence, with a „Burundian" deputy. ${ }^{26,}$

${ }^{25}$ Bjorn Willum, op.cit. hal. 71

${ }^{26}$ Dorsey, p.327. See also Mugabe, „The Killings

Resume..." at

http://www.strategicstudies.org/crisis/rwanda.htm\# Uganda-Rwanda.

Beberapa keterangan tambahan dalam kutipan di atas adalah Gendermarie di Rwanda merujuk pada
Akazu dianggap sering melakukan berbagai pelanggaran atas persetujuan Kagame sebagai orang yang paling berpengaruh dari Akazu. Salah satu contoh yang memperlihatkan dominasi perwira militer Rwanda yang tergabung dalam Akazu terhadap pemerintahan sipil terjadi pada tahun 1996, dimana seorangkolonel RPA memaksa menteri keuangan Rwanda pada waktu itu, Marc Ruganera, untuk memberikan sejumlah uang:

[In 1996] then Minister of Finance,
Marc Ruganera, was asked point blank
by an RPA colonel to give him US\$
500,000 "to take care of urgent matters".
When asked to state in greater detail
what the money was for he said it was to
pay his men. The Minister then asked
him for a detailed list of personnel for
whom this money was earmarked and
what their salaries were. Whereupon the
Colonel exploded and told Ruganera
that he would "hear about it". Later,
President Paul Kagame phoned
Ruganera and told him to pay the US\$
500,000 to the Colonel "for the good of
the country". Ruganera did not push the
matter any further and arranged for
payment of the monies. This illustrates
fairly well the relationship between the
Army and the civiliangovernment. ${ }^{27}$,

Kagame menggunakan Akazu untuk mencegah kelompok non-Akazu yang terdapat dalam berbagai kementerian untuk melakukan penyelidikan atas pelanggaran kemanusiaan yang dilakukan Rwanda di Republik Demokratik Kongo dan berbagai pemasukan ekonomi yang didapat secara illegal dari penjualan berbagai mineral. Congo Desk, sebuah badan yang dibentuk oleh Biro LuarNegeri (External Security Department) yang terdapat dalam DMI atau Department of Military Intelligence, adalah salah satu wujud dari Akazu dalam invasi Rwanda ke Republik Demokratik Kongo ${ }^{28}$.

kesatuan polisi nasional di Rwanda, „Ugandan“ berarti bekas pengungsi Tutsi yang sebelumnya berdiam di Uganda, berlaku selanjutnya untuk „Burundian“e dan Zairian

${ }^{27}$ Willum, Ibid, hal.

${ }^{28}$ Kris Berwots, Cracks in the mirror as Rwanda prepares for 2010 elections, European Network of Central Africa, hal.5 
Menurut laporan Panel PBB dengan nomor S/PRST/2001/39, Congo Desk adalah jaringan komersial dan perdagangan yang dimiliki oleh RPA. Congo Desk sendiri diawasi oleh James Kabarebe, bekas Kepala Angkatan Bersenjata RDK yang berasal dari RPA dan sekembalinya ke Rwanda langsung diangkat menjadi Menteri Pertahanan oleh Paul Kagame. Menurut laporan Jordi Palau Loverdosdalam laporannya untuk Material of Peace and Human Right, berbagai tambang strategis di wilayah pengaruh Rwanda dilindungi oleh RPA, sedangkan untuk masalah merebut koltan yang dikuasai oleh komunitas lokal maupun milisi yang kontra Rwanda dan urusan transportasi mineral adalah tanggung jawab DMI. semua eksploitasi yang dilakukan oleh prajurit Rwanda berlangsung atas sepengetahuan intelijen militer Rwanda atau Directorate for Military Intelligence yang bekerja untuk kepentingan Congo Desk ${ }^{29}$. PBB sendiri memiliki daftar namanama perwira yang tergabung dalam Congo Desk dan merekomendasikan kepada negara-negara anggota PBB untuk mengenakan larangan perjalanan terhadap nama-nama tersebut ${ }^{30}$.

Beberapa perusahaan yang berafiliasi dengan Congo Desk dalam perdagangan koltan adalah Rwanda Metals dan Grand Lac Metals. Pemegang saham dari Rwanda Metals adalah Mayor Kazura, Kepala Keamanan RPA di RDK, sedangkan Grand Lac Metals adalah Mayor Dan Munyuza, salah satu petinggi Congo Desk diKigali ${ }^{31}$.

Semenjak semua koltan yang diperoleh oleh perantara atau comptoir di Kivu dikuasai oleh RPA dan milisi yang menjadi proxy, RCD, semua koltan tersebut dijual ke Rwanda Metals atau Grand Lacs Metals. Selanjutnya, Rwanda harus mengangkut koltan yang mereka peroleh

\footnotetext{
${ }^{29}$ Jordi Palou Loverdos, International Justice, Plunder in War, Human Multinationals(Material of Peace and Human Rights: Department of International Relations Catalunya), hal. 20
}

dari Kigali untuk sampai ke mitra usaha mereka yang berada di berbagai negara. Tentunya, perusahaan pengangkutan atau transport companies yang menjadi mitra usaha Rwanda dalam pengangkutan koltan, sudah mengenal para perwira militer pada kedua perusahaan tersebut dan menjalin hubungan baik. Chris Huber dan Viktor Bout adalah beberapa nama yang dianggap memiliki kedekatan dengan militer Rwanda, dan memiliki kontribusi dalam mengangkut mineral-mineral dan senjata untuk Rwanda dan RCD sebagai proxy dari Rwanda.

\section{Analisa Kerjasama Pemberontak pro- Rwanda dan Militer Rwanda dalam Eksploitasi Mineral Menggunakan Warlordism}

Selama Perang Kongo berlangsung, Rwanda diketahui menggunakan 2 gerakan pemberontak sebagai proxy mereka selama invasi, yakni ADFL Alliance des Forces Démocratiques pour la libération $d u$ Congo atau selama Perang Kongo Pertama dan RCD atau Rassemblement Congolaise pour la Démocratie selama Perang Kongo Kedua. Hal tersebut bisa dilakukan Rwanda dikarenakan dalam Perang Kongo, dapat ditemukan ketidakpuasan terhadap rezim yang berkuasa di RDK selama dua Perang Kongotersebut.

Laurent Kabila, yang merupakan pemimpin ADFL, bagi Rwanda adalah orang yang tepat untuk mengaburkan invasi Rwanda di RDK. Walaupun Kabila tidak populer di mata rakyat, namun asal Rwanda dapat mempersenjatai Kabila dan ADFL untuk menggulingkan Mobutu Sese Seko, makan Kabila dapat mengizinkan pasukan Rwanda untuk beroperasi di RDK. Untuk membuktikan pada Kabila bahwa Rwanda bersungguh-sungguh ingin membantu Kabila, Rwanda memanfaatkan hubungan baik negara tersebut dengan Amerika Serikat untuk mempersenjatai ADFL. Kedatangan Mike Murrough, teman Bill Clinton dan juga utusan dari AMF dan berbagai perusahaan lainnya menambah pendanaan ADFL dalam pertempuran melawan Mobutu Sese Seko ${ }^{32}$. Sementara

${ }^{32}$ Dena Montague, The Bussiness of War in Democratic Republic of Congo, 
itu, RCD mengklaim bahwa perjuangan yang mereka lakukan adalah untuk membebaskan RDK dari kediktatoran Laurent Kabila, namun anggaran yang RCD miliki harus dikelola dan diketahui oleh Rwanda sebagai sponsor utama mereka dan setiap operasi militer yang RCD lakukan diawasi oleh perwira Rwanda membuat gerakan ini kurang mendapat simpati dari rakyat RDK pada umumnya. Namun walaupun memiliki dukungan politik yang rendah, karena kontribusi Rwanda secara materil membuat RCD bisa terus memperkuat diri melalui kekuatan militer. Presiden Paul Kagame bahkan tidak malu mengakui kerjasama Rwanda dengan RCD. Menurutnya, kerjasama Rwanda dan RCD dapat dilihat sebagai bentuk persaudaraan, ketika ditanya oleh pejabat Bank Dunia mengenai bagaimana Rwanda menghidupi pasukan mereka yang berada di Republik Demokratik Kongo dengan anggaran resmi militer Rwanda: ${ }^{33}$

\section{from Punia or Walikale, it's up to them." "It is a brotherhood. ... If the Rwandans come} and they get col-tan

Suplai koltan yang berasal dari RCD dan kemudian dijual kepada Rwanda dapat menjelaskan mengapa para perantara yang bekerjasama dengan RCD dan Rwanda dapat memperbaiki kualitas hidup mereka, sedangkan 35.000 prajurit Rwanda pada tahun 2001 bisa dibilang memiliki perlengkapan yang memadai, digaji secara tetap, dan memiliki kualitas hidup yang baik.

Seperti yang sebelumnya disebutkan, berkat dukungan dari Rwanda, RCD memiliki kapabilitas untuk menolak berbagai perjanjian perdamaian yang bertujuan untuk melucuti senjata pihak-pihak yang bertempur dalam Perang

http://www.thirdworldtraveler.com/Africa/Business War_Congo.html, diakses 10 April 2015 jam 3:11 WIB

${ }^{33}$ MenurutartikelVital ore funds Congo's war di Washington Post padatanggal 19 Maret 2001, 2 wilayah tersebut memiliki koltan dengan kualitas tinggi.
Kongo Kedua. Ada berbagai perjanjian perdamaian sebelum Sun City Agreement yang menyepakati adanya pemerintahan transisi, dan proses perdamaian berlangsung lebih lama karena RCD turut menyumbang kontribusi dalam menolak berbagai perjanjian tersebut. Perjanjian Sirtre dan Lusaka ditolak oleh RCD karena berbagai alasan seperti tuduhan genosida kepada Rwanda, tidak dilibatkannya perwakilan RCD dalam perjanjian tersebut, maupun berbagai kepentingan strategis lainnya. Bagi Rwanda, RCD diperlukan sebagai kedok dimana melalui RCD pemberontakan dibuat seolah-olah datang dari rakyat RDK. Dennis Tull menuliskan ini mengenai kegunaan RCD bagi Rwanda:
" to help RCD establish a strong power base on both an elite level as well as on the ground by forging close link between Kigali, RCD, and the Banyarwanda, recruitment between Banyamulenge repatriatee to Rwanda influence, and promoting humanitarian concern by protect Banyarwanda, also able to channel international aid to financing Kigali and allies in Congo." ${ }^{34}$

\section{PENUTUP}

Pada bagian akhir ini, dapat ditarik kesimpulan berkenaaan dengan kepentingan ekonomi Rwanda dalam Perang Kongo yaitu eksploitasi alam yang dilakukan oleh Rwanda dipengaruhi oleh kurangnya infrastruktur dan lebih cenderungnya tanah digunakan sebagai lokasi pertanian dibanding pertambangan .Sumber daya alam yang dieksploitasi digunakan untuk memperbaiki situasi ekonomi Rwanda yang sudah lama bergantung pada ekspor teh dan kopi, memperbaiki neraca perdagangan yang menjadi syarat untuk meminjam bantuan keuangan seperti dari IMF, dan secara laten adalah untuk memperkaya orang- orang yang dekat dengan Presiden Paul Kagame.

Kepentingan ekonomi dari Rwanda sendiri mulai muncul ketika Laurent Kabila, orang yang didukung Rwanda, mengusir pasukan Rwanda dari RDK 
sekaligus memutus kontrak perusahaanperusahaan yang berasal dari negara yang dekat dengan Rwanda. Hal ini membuat Rwanda memutuskan untuk memiliki proxy yang bisa mereka awasi gerak geriknya sekaligus mengambil keuntungan dari eksplotasi yang proxy mereka lakukan. Rwanda sendiri dapat mengambil keuntungan dari wilayah-wilayah yang pemberontak kuasai dan korupnya birokrasi RDK selama perang berlangsung.

Untuk memperoleh kepentingan ekonomi tersebut, Rwanda memanfaatkan lemahnya kendali tentara pemerintah RDK atas tambang-tambang yang berada di negara tersebut. Rwanda sendiri mampu memanfaatkan ketidaksenangan yang terdapat di dalam RDK terkait pemerintahan otoriter, angkatan bersenjata yang tidak kompeten, krisis ekonomi, dan masalah lainnya, sehingga berbagai milisi yang dibentuk untuk menggulingkan pemerintahan berkuasa RDK, beberapa di antara mereka berada di bawah pengawasan Rwanda, seperti ADFL dan RCD. Milisi yang diawasi dan dibentuk oleh Rwanda terbukti dapat menandingi keberadaan angkatan bersenjata RDK, terbukti dengan milisi ADFL pada Perang Kongo Pertama yang mampu melakukan serangan langsung ke Kinshasa, ibukota RDK, dan ADFL, yang mampu membentuk pemerintahan sendiri di wilayah perbatasan Rwanda-RDK dan melakukan eksploitasi mineral untuk keuntungan mereka sendiri. Mineral yang Rwanda peroleh kemudian dijual ke luar negeri. Mineral yang diperoleh oleh Rwanda di RDK mampu menjadikan negara tersebut sebagai negara penghasil mineral yang terkemuka, walaupun seperti yang dijelaskan sebelumnya, persediaan tanah di Rwanda semakin menyusut disebabkan perkebunan kopi. 


\section{DAFTAR PUSTAKA}

\section{Buku}

Clark, John F. (ed.), The African Stakes of Congo War, New York: Palgrave Macmillan, 2004

Gebrewold, Belachew, Anatomy of Violence: Understanding the System of Conflict and Violence in Africa, Burlington :Ashgate,2009

Reyntjens, Filip, The Great African War, Congo and Regional Politics, Cambridge: New York, 2009

Ngolet, François, Crisis in The Congo: The Rise and Fall of Laurent Kabila, New York :Palgrave Macmillan, 2011

Maryssee, Stefan danFilipReyntjens, The Political Economy ofthe Great Lakes Region in Africa The Pitfalls of Enforced Democracy and Globalization, New York: Routledge, 2005

Straus, Scoot dan Lars Waldorf, Remaking Rwanda: State Building and Human Rights after Mass Violence, London: University of Wisconsin Press, 2011

Moleong, Lexy J. Metodologi Penelitian Kualitatif. Bandung : $\quad$ PT RemajaRosdakarya,2000

Alou, Abioudun, Natural Resources and Conflict in Africa : The Tragedy of Endowment, New York: University of Rochester Press, 2007

Stearns, Jason K, Dancing in the Glory of Monster: The Collapse of the Congo and Great War of Africa, Public Affairs Press, 2012

Lansford, Tom (ed.), Political Handbook of the World 2014,New York: SAGE Publishing,2014

Cooper, Tom, Great Lake Conflagration: Second Congo War 1998-2003, West Midland:Helion and Company Limited,2013

Schmidt, Elizabeth, Foreign Intervention in Africa: From the Cold War to the War on Terror. New York: Cambridge University Press, 2013

\section{Jurnal, Paper danLaporan}

Bigagaza, Jean, Carolyn Abongdan Cecile Mukarubuga, Land Scarcity, Distribution and Conflict in Rwanda, Pretoria: Institute for Security Studies, 2002,

Boudreaux, Karol C. dan Puja Ahluwalia, Cautiously Optimistic: Economic Liberalization and Reconciliation in Rwanda Coffee"s Sector, World Bank, 2010

Willum, Bjorn, Foreign Aid to Rwanda: Totally Beneficial or Contributing to War, University of Copenhagen,2001

Fieldstad, Hanne Katherine ,Rwanda in the DRC: Keeping the PotBoiling,

Mastes diss., Oslo University, 2010 
Williams, Christopher, Explaining Great War in Africa:How Conflict in Congo become Continental Crisis, The Fletcher Forum of World Affairs Vol. 37 Issue 2, 2013

Celine Moyroud and John Katunga,Coltan Exploration in Republic Democratic of Congo ,Pretoria: Institute for Security Studies, 2002

Samset, Ingrid, Conflict of Interest or Interest in Conflict: Diamonds and War in the DRC, Review of African Political Economy, ROAPE Publishing, 2001

Billon, Phillipe L., The Geopolitics of Resource Wars: Resource Dependence,

Governance and Violence, London: Frank Cass Publisher, 2007

Veerwimp, Philip, The 1990-1992 Massacres in Rwanda: A Case of Spatial and Social Engineering, University of Sussex,2011

, Assessing USAID"S Investments in Rwanda"s CoffeeSector-Best Practices and Lessons Learned to Consolidate Results and Expand Impact,USAID,2006

, Scramble for the Congo: Anatomy of Ugly War, Brussels: International Crisis Group,2001

Columbus, Frank A. (ed.), Politics and Economies in Africa: Volume 1,NewYork:Nova Publisher, 2001

Bizimana, Ladislas, Conflict in African Great Lake Region: A Critical Analysis of Regional and International Involvement, ( University of Deusto, Bilbao), 1995

,Coltan, Congo and Conflict, Polinares Case Study: Hague,2013

Tshishlmbi ,Bilengadan Peter Glick, Economic Crisis and Adjustment in Zaire, 1993, Cornell: Cornell University

Willame (ed.), Zaire: Predicament and Prospects, Washington: United States Institute of Peace, 1999

Raeymaekers, Timothy, The Power of Protection Governance and Transborder Trade on the Congo-Ugandan Frontier,Doctor thesis, Ghent University, 2007

Curtis, Marcus, Raison d"État Unleashed: Understanding Rwanda"s Foreign Policy in the Democratic Republic of the Congo, Center for Contemporary Conflict, 2005 
Arinaldo Habib Pratama | Kepentingan Ekonomi Rwanda dalam Perang Kongo

Eriksen, Stein Sundstøl, The Congo war and the Rwanda and Uganda compared prospects of state formation, Oslo: Norwegian Institute of International Affairs, 2005

Pottier, Johan, Everybody needs good neighbours: understanding the conflict(s) in

Eastern DRC, Lisboa: Centro de EstudosAfricanos do ISCTE, 2002

Jones, Will, Africa"s Illiberal State-builders, Oxford: Refugee Studies Centre, 2013

Booth, David, Developmental patrimonialism? :The case of Rwanda,London: Africa Power and Politics Programme

Naidoo (ed.), The War Economy in the Democratic Republic of Congo, Institute for Global Dialogue, 2002

Hartung, William D.,Deadly Legacy: U.S. Arms to Africa \& the Congo War, NY,World Policy Inst. Jan. 2000

Kris Berwots, Cracks in the mirror as Rwanda prepares for 2010 elections, European Network of Central Africa

, The War Within The War:Sexual Violence Against Women and Girls in Eastern Congo,NewYork:Human Right Watch

Tull, Dennis M. , The Reconfiguration of Political Order in Africa: Case Study North Kivu, Hamburg: Institute of African Affair, 2005

Taka, Miho, Conflict Coltan: Local and International Dynamics in the Democratic Republic of Congo, Conventry University,2008

Say, Laura E., What"s Wrong with Dodd-Frank 1502? Conflict Minerals, Civilian Livelihoods, and the Unintended Consequences of Western Advocacy, Washington DC, Center for Global Development, 2012

\section{BIOGRAPHY}

Arinaldo Habib Pratama, mendapatkan gelar Sarjana Ilmu Politik pada tahun 2015 dari Jurusan Ilmu Hubungan Internasional Universitas Andalas. Mulai dari Juni 2017 sampai saat ini sedang menjalankan studi pascasarjana di Prodi Manajemen Pertahanan, Fakultas Manajemen Pertahanan, Universitas Pertahanan. Research interest dari penulis adalah kajian keamanan dan sekuritisasi. Memiliki pengalaman kerja selama 1.5 tahun (Juni 2015-Desember 2016) sebagai jurnalis di media-media seperti DetikFinance, Jitunews dan Bola.com. 